\title{
O ENSAÍSMO PRESENTE EM SE UM VIAJANTE NUMA NOITE DE INVERNO, DE ITALO CALVINO: UMA TEORIA DA LEITURA EM UM ROMANCE METALITERÁRIO
}

\author{
Juliana Ramos* \\ Universidade do Estado do Rio de Janeiro
}

\begin{abstract}
Resumo: Este estudo propõe uma reflexão sobre como o pensador Italo Calvino evidencia em Se um viajante numa noite de inverno (1979) uma teoria da leitura. Nesse romance, enquanto o escritor narra a tentativa do personagem chamado Leitor de terminar a leitura de um livro, ele também teoriza sobre o leitor e a leitura. Dentre as muitas possibilidades de análise dessa obra, tendo em vista sua multiplicidade, é focado a exposição, no próprio texto, do processo de escrita do romance e da sua ficcionalidade. O recorte escolhido tem sua relevância justificada pela proposição de Jean Baudrillard em Simulacros e simulação (1991): a "promessa", uma vez que ainda não havia se revelado na época desta publicação, da terceira categoria de simulacro, na qual já não haveria o isolamento de ficção e teoria e em que a indistinção entre imaginário e real abriria caminho para a presentificação da metatécnica; essa categoria é percebida na obra estudada e é a que, segundo Baudrillard, ainda pode interessarnos. Se um viajante numa noite de inverno, porquanto espaço de articulação metaliterária, é um ambiente profícuo de interação entre ficção e teoria, sendo, portanto, ainda mais produtivo para o debate sobre a figura e a função do leitor. É precisamente o aspecto metaliterário relacionado à figura do leitor e à sua atividade o que é rastreado nesse texto que o próprio escritor denominou hiper-romance. Para isso, identifica-se e analisa-se alguns aspectos distintivos dessa obra quanto a: como ler, tipos de livros, a arte de não-ler, leitor e leitura; de modo que o objeto literário de estudo é também parte do corpus teórico selecionado. À produção ficcional e teórica de Italo Calvino, soma-se os construtos teóricos de Wolfgang Iser e Jorge Luis Borges para a compreensão e análise do texto literário em foco quanto aos temas centrais desenvolvidos aqui: leitor e leitura.
\end{abstract}

Palavras-chave: Italo Calvino. Leitor. Leitura. Metaliteratura.

Italo Calvino é considerado um dos mais proeminentes escritores italianos do século XX. No próximo ano, completa-se trinta anos de sua morte, e sua arte e seu pensamento

\section{(i) 9}

EY NC ND Esta obra está licenciada sob uma Licença Creative Commons.

\footnotetext{
* Doutoranda em Literatura Comparada pela Universidade do Estado do Rio de Janeiro (UERJ). E-mail: ramos2.juliana@gmail.com.
}

Anu. Lit., Florianópolis, v. 20, n. Esp 1, p. 156-169, 2015. ISSNe 2175-7917 
continuam repercutindo na produção e recepção das mais diversas obras. Isso porque sua produção artística, como um corpo orgânico, reflete seu olhar crítico-interpretativo para a realidade, o que, portanto, não significa que sua obra seja marcada por uma espécie de realismo.

São muitos os temas e os recursos estéticos desenvolvidos nas produções de Calvino. No entanto, interessa a este estudo a observação do texto enquanto espaço de presentificação da metatécnica - nos termos de Baudrillard para a descrição da terceira categoria de simulacro que se instauraria -, de articulação entre ficção e teoria, manifestando-se como um entrelugar, um espaço plural e fragmentado, marcado por descentramento e heterogeneidade, capaz de comportar até o contraditório (BHABHA, 1998).

Esse ambiente é propriamente o de narrativas como Se um viajante numa noite de inverno (1979). Nesse livro, Calvino discute questões relacionadas à criação e à recepção literárias, porém o que mais pode interessar é o fato de o autor refletir sobre a recepção enquanto processo de criação, tratando, ainda, de assuntos como: o modo de ler, tipos de livros, a arte de não-ler, leitor e leitura.

Sendo assim, neste trabalho, investiga-se a forma como o escritor Italo Calvino evidencia uma teoria da leitura no livro Se um viajante numa noite de inverno. Nesse romance, enquanto é narrada a tentativa do personagem chamado Leitor de terminar a leitura de um livro, teoriza-se sobre a figura e o papel do leitor bem como sobre a sua ação, a leitura. Todavia, o papel do Leitor não se resume a contextualizar a narrativa, pois ele e os demais personagens-leitores formam uma rede de discursos e ações que transformam esse livro, chamado pelo próprio autor de hiper-romance, em, mais do que uma reflexão sobre a criação literária, uma reflexão sobre uma recepção literária produtiva.

No início do romance, o tom já é dado: "Você vai começar a ler o novo romance de Italo Calvino, Se um viajante numa noite de inverno" (CALVINO, 2003, p. 11). Esta é a primeira frase que o leitor explora, e o estranhamento é inevitável. A narrativa rompe com o esperado ao ocupar-se do receptor e de si própria, dobrando-se sobre si mesma, assim como o leitor debruça-se sobre ela.

No primeiro capítulo, o qual é homônimo do livro, percebe-se, ainda, a presença de assuntos próprios do interesse do leitor e do estudo dessa figura. Este é o caso da extensa lista de tipos de livros desenvolvida, na qual se trata também, por inferência, da arte de ler e da arte de não ler: 
tentando intimidá-lo. Mas você sabe que não deve deixar-se impressionar, pois são distribuídos por hectares e mais hectares os Livros Cuja Leitura É Dispensável, os Livros Para Outros Usos Que Não a Leitura, os Livros Já Lidos Sem Que Seja Necessário Abri-los, pertencentes que são à categoria dos Livros Já Lidos Antes Mesmo de Terem Sido Escritos. Assim, após você ter superado a primeira linha de defesas, eis que cai sobre sua pessoa a infantaria dos Livros Que, Se Você Tivesse Mais Vidas Para Viver, Certamente Leria De Boa Vontade, Mas Infelizmente Os Dias Que Restam Para Viver Não São Tantos Assim. Com movimentos rápidos, você os deixa para trás e atravessa as falanges dos Livros Que Tem A Intenção De Ler Mas antes Deve Ler Outros, Dos Livros Demasiados Caros Que Podem Esperar Para Ser Comprados Quando Forem Revendidos Pela Metade do Preço, dos Livros Idem Quando Forem Reeditados Em Coleções De Bolso, dos Livros Que Poderia Pedir Emprestado A Alguém, dos Livros Que Todo Mundo Leu E É Como Se Você Também Os Tivesse Lido. Esquivando-se de tais assaltos, você alcança as torres do fortim, onde ainda resistem

os Livros Que Há Tempo Você Pretende Ler,

os Livros Que Procurou Durante Vários Anos Sem Ter Encontrado,

os Livros Que Dizem Respeito A Algo Que O Ocupa Neste Momento,

os Livros Que deseja Adquirir Para Ter Por Perto Em Qualquer Circunstância, os Livros Que Gostaria De Separar Para Ler Neste Verão,

os Livros Que Lhe Faltam Para Colocar Ao Lado De Outros Em Sua Estante,

os Livros Que De Repente Lhe Inspiram Uma Curiosidade Frenética E Não Claramente Justificada.

Bom, foi enfim possível reduzir o número ilimitado de forças em campo a um conjunto certamente muito grande, conquanto calculado num número finito, embora esse alívio relativo seja solapado pelas emboscadas dos Livros Que Você Leu Há Muito Tempo E Que Já seria Hora De Reler e dos Livros Que Sempre Fingiu Ter Lido E Que Seria Hora De Decidir-se A Lê-los Realmente.

Você se livra com rápidos ziguezagues e, de um salto, penetra na cidadela das Novidades Em Que O Autor Ou O Tema São Atraentes. Uma vez no interior dessa fortaleza, pode abrir brechas entre as fileiras de defensores e dividi-los em Novidades De Autores Ou Temas Já Conhecidos (por você ou por todos) e Novidades De Autores Completamente Desconhecidos (ao menos para você) e definir a atração que eles exercem sobre você segundo suas necessidades e desejos de novidade e não-novidade (da novidade que você busca no não-novo e do nãonovo que você busca na novidade).

Tudo isso para dizer que, após ter percorrido rapidamente com o olhar os títulos dos volumes expostos na livraria, você se dirigiu a uma pilha de exemplares recémimpressos de se um viajante numa noite de inverno, pegou um e o levou ao caixa para ver reconhecido o seu direito de possuí-lo. (CALVINO, 2003, p. 13-14)

Nesse caminho percorrido por entre os livros Que Lemos Ou Leremos e os Que Não Lemos Nem Leremos, como em uma grande labiríntica biblioteca própria da constituição de cada leitor, percebe-se que o relato assemelha-se à narração de uma aventura, que seria a aventura do leitor até conquistar o Se um viajante numa noite de inverno. Mas o que o leitor conquistaria com essa leitura?

Ao perceber o tom metaliterário dessa obra e deparar-se com esse questionamento,

Agora, sim, você está pronto para devorar as primeiras linhas da primeira página. Está preparado para reconhecer o inconfundível estilo do autor. Não, você não o está reconhecendo. Mas, pensando bem, quem afirmou que este autor tem estilo inconfundível? Pelo contrário: sabe-se que é um autor que muda muito de um livro para outro. E é justamente nessas mudanças que se pode reconhecê-lo. No entanto, parece que este livro nada tem a ver com os outros que ele escreveu, pelo menos com aqueles dos quais você se lembra. Está desapontado? Vejamos. De início você 
talvez experimente certo desnorteamento, como o que sobrevém quando somos apresentados a uma pessoa que pelo nome parecia identificar-se com determinada fisionomia, mas que, ao tentarmos fazer coincidir os traços do rosto que vemos com os daqueles de que nos lembramos, percebemos não combinar. Mas depois você prossegue na leitura e percebe que de algum modo o livro se deixa ler, independentemente daquilo que você esperava do autor. O livro é o que desperta sua curiosidade; pensando bem, você até prefere que seja assim, deparar com algo que ainda não sabe bem o que é. (CALVINO, 2003, p. 17)

O autor estabelece diálogo direto com o leitor e não o pacifica, antes o confronta, já adiantando que sua participação não será passiva. E o escritor deixa claro que é do livro, do texto, que se deve esperar algo. Assim como afirmou ao dizer: "Espero que meus leitores leiam em meus livros algo que eu não sabia, mas só posso esperar isso daqueles que esperam ler algo que eles não sabiam" (CALVINO, 2003, p. 189). Desse modo, percebe-se que a relação é recíproca: o texto atua sobre o leitor, e o leitor atua sobre o texto. Este não é um objeto acabado, e, nas palavras empregadas por Calvino, também não é inacabado, mas “"acabado interrompido', 'acabado cujo final está oculto ou ilegível', tanto no sentido literal como no metafórico" (CALVINO, 2003, p. 268), deixando sempre o leitor a perguntar: "Que história espera seu fim lá embaixo?”(CALVINO, 2003, p. 261).

Se um viajante numa noite de inverno forma um conjunto de dez narrativas diversas interrompidas e funciona (na trilha do OULIPO) como uma amostragem da multiplicidade potencial do narrável. No entanto, funciona também como amostragem da multiplicidade potencial da leitura, pois intensifica, por meio da reiteração, o papel ativo do receptor, e "é a ação da leitura que se torna decisiva; é do leitor o papel de fazer com que a literatura explique a sua força crítica e isto pode vir independente da intenção do autor" (CALVINO, 1995, p. 10). Trata-se do papel ativo do leitor na realização da obra.

O leitor de literatura, a priori, deve contemplar toda a complexidade do objeto; não apenas olhar, mas inspecionar.

\begin{abstract}
Envolve não apenas a visão e percepção, mas inferência, julgamento, memória, reconhecimento, conhecimento, experiência e prática. [...] Ler, então, não é um processo automático de capturar um texto como um papel fotossensível captura a luz, mas um processo de reconstrução desconcertante, labiríntico, comum e, contudo, pessoal. (MANGUEL, 1997, p. 49-54)
\end{abstract}

Desse modo, a leitura não é um processo passivo; é a partir dela que o texto é ativado.

Pode-se dizer que o texto é um dispositivo potencial baseado no qual o leitor, por sua interação, constrói um objeto coerente, um todo. [...] O sentido é, pois, um efeito experimentado pelo leitor, e não um objeto definido, preexistente à leitura. [...] Como em Ingarden, o texto literário é caracterizado por sua incompletude e a literatura se realiza na leitura. A literatura tem, pois, uma existência dupla e 
heterogênea. Ela existe independentemente da leitura, nos textos e nas bibliotecas, em potencial, por assim dizer, mas ela se concretiza somente pela leitura. O objeto literário autêntico é a própria interação do texto com o leitor. [...] O objeto literário não é nem o texto objetivo nem a experiência subjetiva, mas o esquema virtual (uma espécie de programa ou de partitura) feito de lacunas, de buracos e de indeterminações. Em outros termos, o texto instrui e o leitor constrói. Em tal texto os pontos de indeterminação são numerosos como falhas, lacunas, que são reduzidas, suprimidas pela leitura. (COMPAGNON, 1999, p. 149-150, grifos do autor)

Como a metáfora de Sartre indica, "o objeto literário é um estranho pião que só existe em movimento. Para fazê-lo surgir é preciso um ato concreto que se chama leitura e ele só dura enquanto essa leitura puder durar" (SARTRE apud COMPAGNON, 1999, p. 148). Para que se realize, a literatura precisa ser compreendida em sua dimensão estética, e isso demanda tempo de apreensão, assimilação e, se ocorrer, apropriação. "O processo de leitura define-se como a concretização do objeto artístico (obra) em objeto estético (texto)" (AGUIAR, 1996, p. 29).

Como dizer, então, que este é um processo passivo? Independente do gênero, ler requer compreensão e atribuição de sentido, ao texto e ao mundo. Assim, o livro não é o mesmo após o contato com o leitor, e este também é afetado pelo contato com aquele. De modo que, no leitor, percebe-se a construção do conhecimento intelectual e identitário, e, no livro, a sua (re)ssignificação como objeto estético.

No prefácio da primeira edição de "O ato da leitura", Iser enfatiza a relevância da leitura, uma vez que "não podemos captar exclusivamente o efeito [do texto literário] nem no texto, nem na conduta do leitor; o texto é um potencial de efeitos que se atualiza no processo da leitura" (ISER, 1996, p. 15).

A leitura é o esforço marcado pelo reconhecimento e a criação de sentidos; é a relação desenvolvida a partir da tríade autor, texto e leitor. $\mathrm{O}$ autor produz o enredo e os elementos que o compõem, mas o leitor é quem atribui existência de objeto estético ao texto. $\mathrm{Na}$ medida em que este se manifesta enquanto obra inacabada e aberta, mostra-se aos inúmeros olhares interpretativos. O leitor não está fadado a uma interpretação uníssona guiada pela voz da autoria, antes interage com o texto e o autor implícito dando muito de si e tomando muito deles. As experiências do leitor estão imbricadas à sua prática, bem como as do autor estiveram e permanecem em traços da narrativa.

A partir da relação dialética entre autor, texto e leitor, tem-se a construção de sentido, de modo que a obra torna-se arte, produz um efeito estético, o qual ocorre de tantas maneiras quantos forem os leitores, e tantas quantas forem as leituras, pois um mesmo leitor, ao 
recolocar-se frente a um texto, será, na verdade, outro e, em vista disso, sua prática será diferente, (re)ssignificando a si e ao texto de outra maneira.

Outro teórico a ser considerado neste estudo é Umberto Eco. Porquanto a teoria de Iser e Eco aproximam-se em muitos pontos, muitos termos apresentam pontos de congruência, sobretudo, respectivamente: leitor implícito/leitor-modelo e repertório/enciclopédia, além da noção de vazio que dá procedência à teoria dos espaços vazios, de Iser, e à da obra aberta, de Eco.

Wolfgang Iser, na teoria dos espaços vazios, postula a existência de lacunas no texto a serem preenchidas pelo leitor na sua prática, de modo a tornar o leitor partícipe da construção de sentido do texto.

Como interrupção da coerência do texto, os vazios se transformam na atividade imaginativa do leitor. Alcançam desta maneira o caráter de uma estrutura autoreguladora, à medida que convertem o que subtraem em impulso para a consciência imaginante do leitor: o ocultado transparece pelas representações. (ISER, 1979, p. 120)

O leitor participa tornando evidente aquilo de si que ocupa o vazio daquilo do autor que no texto está omitido; ele "chega a fingir que é dor / A dor que deveras sente" (PESSOA, 1986, p. 314). O leitor preenche as lacunas do texto, articulando perspectivas.

\begin{abstract}
O texto é um sistema de combinações e assim deve haver também um lugar dentro do sistema para aquele a quem cabe realizar a combinação. Este lugar é dado pelos vazios [...] no texto, que assim se oferecem para a ocupação pelo leitor. Como eles não podem ser preenchidos pelo próprio sistema, só o podem ser por meio doutro sistema. Quando isso sucede, se inicia a atividade de constituição, pela qual tais vazios funcionam como um comutador central da interação do texto com o leitor. Donde, os vazios regulam a atividade de representação [...] do leitor, que agora segue as condições postas pelo texto. [...] Os vazios possibilitam as relações entre as perspectivas de representação do texto e incitam o leitor a coordenar estas perspectivas. (ISER, 1979, p. 91).
\end{abstract}

Os vazios são como “"articulações do texto', pois funcionam como as 'charneiras mentais' das perspectivas de representação e assim se mostram como condições para a ligação entre os segmentos do texto" (ISER, 1979, p. 106). O sentido do texto é construído no processo de interação entre o texto e o leitor, na leitura. "À medida que os vazios indicam uma relação potencial, liberam o espaço das posições denotadas pelo texto para os atos de projeção [...] do leitor” (ISER, 1979, p. 106).

Iser alude à metáfora do viajante como forma de conceber o ato da leitura, que é um processo de projeção individual. Nessa perspectiva, o leitor é quem preenche, a seu modo, com maior ou menor grau de consciência a respeito de sua prática, as lacunas deixadas pelo autor no texto. O leitor empírico é um viajante que se desloca pelo texto formando um 
itinerário coerente, alterando o seu ponto de vista conforme o seu percurso, no qual é atravessado pelas perspectivas presentes no texto.

Um exemplo característico é a metáfora da diligência usada por Fielding e mais tarde por Scott e seus discípulos: o leitor é estilizado como viajante que, através do romance, empreende uma viagem difícil, a partir de seu ponto de vista flutuante. É evidente que ele combina, em sua memória, tudo que vê e estabelece um padrão de consistência, cuja confiabilidade depende parcialmente do grau de atenção que manteve em cada fase da viagem. Em nenhum caso, porém, a viagem inteira é disponível para o leitor a cada momento. (ISER, 1996, p. 44-45).

Porém, Iser não se refere ao leitor empírico; postula a ideia de leitor implícito, um tipo de receptor idealizado pelo autor e demarcado no texto.

o leitor implícito não tem existência real; pois ele materializa o conjunto das preorientações que um texto ficcional oferece, como condições de recepção, a seus leitores possíveis. Em conseqüência, o leitor implícito não se funda em um substrato empírico, mas sim na estrutura do texto. Se daí inferimos que os textos só adquirem sua realidade ao serem lidos, isso significa que as condições de atualização do texto se inscrevem na própria construção do texto, que permitem constituir o sentido do texto na consciência receptiva do leitor. A concepção do leitor implícito designa então uma estrutura do texto que antecipa a presença do receptor. [...] a concepção do leitor implícito enfatiza as estruturas de efeito do texto, cujos atos de apreensão relacionam o receptor a ele.

Em conseqüência, todo texto literário oferece determinados papéis a seus possíveis receptores. [...] o papel do leitor se define como estrutura do texto e como estrutura do ato. (ISER, 1996, p. 73).

Ao propor isso, Iser contrapunha-se às demais análises da figura do leitor na medida em que estas se relacionavam a um substrato empírico. Esse teórico estabelece a diferença entre o leitor implícito e o leitor empírico. Este é o leitor real, que não deveria utilizar exclusivamente suas experiências pessoais como ferramenta de interpretação, com o risco de incorrer no que Eco chama de superinterpretação; antes deveria assumir o papel deixado para ele na tessitura do texto. Dessa forma, sua teoria da leitura está relacionada à estrutura do texto, embora se oponha aos modelos estruturais de leitura. Ao leitor implícito, cabe o preenchimento, por meio da atribuição de sentido e interpretação, dos vazios, dos espaços de indeterminação deixados pelo autor no texto (intencionalmente ou não).

A respeito da leitura, Borges disse:

uma biblioteca é um laboratório mágico onde vivem muitos espíritos encantados. Eles despertam, quando chamados. Fechado, um livro é literal e geometricamente um volume, uma coisa entre outras. Quando um livro é aberto e se encontra com o seu leitor, então ocorre o fato estético. Deve-se acrescentar que um mesmo livro muda em relação a um mesmo leitor, já que mudamos tanto. Voltamos à minha citação predileta, somos o rio de Heráclito. [...] Porque também o texto é o rio mutável de Heráclito. (BORGES, 1983, p. 119) 
Nessa reflexão, o autor trata da leitura de modo geral, independente de gênero, e destaca que o ato de ler é um processo de criação de sentidos. Do entrecruzamento de leitor, autor e texto, cabe ao primeiro a tarefa de (re)ssignificação dos sentidos de modo a instaurar o fato estético. Mas esse processo é diferente em cada conjuntura.

Em outra ocasião de publicação, esse pensamento é retomado da seguinte forma:

\begin{abstract}
uma biblioteca é um gabinete mágico em que há muitos espíritos enfeitiçados. Despertam quando os chamamos; enquanto não abrimos um livro, esse livro, literalmente, geometricamente, é um volume, uma coisa entre as coisas. Quando o abrimos, quando o livro dá com seu leitor, ocorre o fato estético. E, cabe acrescentar, até para o mesmo leitor o mesmo livro muda, já que mudamos, já que somos (para voltar a minha citação predileta) o rio de Heráclito, que disse que o homem de ontem não é o homem de hoje e o homem de hoje não será o de amanhã. Mudamos incessantemente e é possível afirmar que cada leitura de um livro, que cada releitura, cada recordação dessa releitura renovam o texto. Também o texto é o mutável rio de Heráclito. (BORGES, 1999, p. 284)
\end{abstract}

Esse rio faz referência ao recorrente construto teórico de Heráclito, que afirma: “A única constante é a mudança"; "Nada é permanente, a não ser a mudança"; "Tudo flui, nada persiste nem permanece o mesmo". E na metáfora do rio, tem-se: "Nós não podemos nunca entrar no mesmo rio, pois como as águas, nós mesmos já somos outros"; "O homem que volta ao mesmo rio, nem o rio é o mesmo rio, nem o homem é o mesmo homem". ${ }^{1}$

E "o leitor é o rio de Heráclito, assim como o texto" (GUIDIO, s/d, grifo do autor), eles são como água do mesmo e diferente (leia-se: outro) rio, como duplos que são. No entanto, estão sempre em mudança, em constante transformação. Após a leitura, nenhum dos dois é como era antes.

Tendo em vista esse quadro, a tendência seria imaginar que esta investigação enveredaria pelo estudo do leitor empírico. No entanto, embora o diálogo com este leitor prolifere ao longo dessa produção, os leitores de tinta e papel mostraram-se ainda mais interessantes. Os personagens-leitores desse livro são diferentes entre si e oferecem uma possibilidade de análise mais extensa e pertinente. (Nessa medida, este livro mostra mais uma face do caráter ensaístico e também experimental do autor.)

São apresentados ao menos nove tipos de personagens-leitores nesse livro.

O primeiro leitor é o protagonista, o personagem chamado Leitor. Ele, em busca de um livro específico e de satisfazer o seu prazer de ler (este é mais um tema central na obra, assim como o "acabado interrompido" das obras e da leitura), vive uma série de situações que

\footnotetext{
${ }^{1}$ As citações deste parágrafo referem-se a expressões de Heráclito que foram extraídas de: PENSADOR.INFO. Pensamento de Heráclito. Disponível em: $<$ http://pensador.uol.com.br/pensamento de heraclito/>. Acesso em: 13 out. 2012.
} 
se conjecturam como um romance de enigma (ou até policial, em que os fatos são articulados por meio da reconstrução e da dedução) ou, ainda, como uma aventura. Em meio ao trágico e o cômico, ele vive situações inesperadas e conhece figuras diferentes mas complementares, outros leitores, envolvendo-se num labirinto de narrativas e leituras. O Leitor torna latente, ao longo de seu discurso, que "Ler é ir ao encontro de algo que está para ser e ninguém sabe o que será." (CALVINO, 2003, p. 78).

O segundo leitor apresentado é uma mulher, a Leitora, Ludmila. Por ela, o Leitor apaixona-se e, com ela, ele vive uma aventura amorosa, dividido entre o amor ao livro (ou à leitura) - essa divisão também é vista no conto "A aventura do leitor", no livro Amores difíceis - e o amor à essa leitora.

Outro tipo possível de leitor é Irnerio. Esse não seria um leitor comum; ele ressignifica de outra forma: Irnerio faz "coisas com os livros. Alguns objetos" (CALVINO, 2003, p. 153). Ele é um artista plástico, e Ludmila lhe "oferece livros para ser trabalhos, livros que não lhe servem de nada" (CALVINO, 2003, p. 153). No entanto, o livro segue a ser um objeto significável, que possui uma potencialidade de significações e ressignificações, de modo que ele diz: "Não quero dizer que qualquer livro me sirva. Uma obra só me vem se eu a sinto" (CALVINO, 2003, p. 153).

No capítulo onze, há uma discussão sobre livros e leitura e, então, tem-se uma série de passagens definidoras de tipos diferentes de leitores e leituras - o que ocorre em outras ocasiões ao longo do livro, mas esse foi um recorte a ser feito em razão das limitações de tempo e espaço. São apresentados ao menos oito tipos de leitores.

O primeiro leitor mostra-se como um verdadeiro viajante, despreocupado com destinos possíveis; se é que isto é considerado: um fim. A ele, interessa o processo, o percurso, o caminho, a viagem. Ele realiza-se e vive $n a$ e pela leitura.

\footnotetext{
Se um livro me interessa de verdade, não consigo avançar além de umas poucas linhas sem que minha mente, tendo captado uma idéia que o texto propõe, um sentimento, uma dúvida, uma imagem, saia pela tangente e salte de pensamento em pensamento, de imagem em imagem, num itinerário de raciocínios e fantasias que sinto a necessidade de percorrer até o fim, afastando-me do livro até perde-lo de vista. (CALVINO, 2003, p. 257)
}

No entanto, em seguida, em um segundo leitor, temos um exemplo da postura inversa: "minha atenção ao contrário da sua não pode afastar-se das linhas escritas nem por um instante" (CALVINO, 2003, p. 258). Esse é um leitor receoso de afastar-se do texto e, talvez, da intencionalidade que possa estar marcada no texto. Ele lê como se estivesse “escavando à volta, para ver se a pepita se desenvolve em filão. Por isso minha leitura não 
acaba nunca: leio e releio sempre, procurando a confirmação de uma nova descoberta entre as dobras das frases" (CALVINO, 2003, p. 258), o que torna evidente que o livro será tantos quantos forem os leitores, número que é potencializado por quantas forem as leituras - essa é uma reflexão que retoma a reflexão borgiana na comparação do leitor com as águas de um rio (citando Heráclito).

E, então, com um terceiro leitor, tratamos da releitura, e aparece-nos mais uma teorização sobre a leitura, o retorno a um velho conhecido que não apenas se atualiza, mas se renova:

Também eu sinto necessidade de reler os livros que já li - diz um terceiro leitor -, mas a cada releitura me parece estar num livro novo. Será que continuo a mudar e ver coisas que antes não percebera em outra leitura? Ou será a leitura uma construção que ganha forma reunindo um número de variáveis e não consegue repetir-se duas vezes obedecendo à mesma configuração? (CALVINO, 2003, p. 258)

Um quarto leitor intervém:

- Se quiserem insistir na subjetividade da leitura, posso concordar com vocês, mas não no sentido centrífugo que vocês lhe atribuem. Cada novo livro que leio passa a fazer parte daquele livro abrangente e unitário que é a soma de minhas leituras. Isso não acontece sem esforço; para compor esse livro geral, cada livro particular deve transformar-se, relacionar-se com os livros que li anteriormente, tornar-se o corolário ou o desenvolvimento ou a refutação ou a glosa ou o texto de referência. Há muitos anos frequento esta biblioteca e a exploro volume por volume, prateleira por prateleira, mas poderia demonstrar-lhes que não fiz outra coisa senão prosseguir na leitura de um único livro. (CALVINO, 2003, p. 259)

Esse leitor torna evidente o assunto da discussão: a subjetividade da leitura. E traz para o debate mais uma ideia já defendida por Calvino.

quem somos nós, quem é cada um de nós senão uma combinatória de experiências, de informações, de leituras, de imaginações? Cada vida é uma enciclopédia, uma biblioteca, um inventário de objetos, uma amostragem de estilos, onde tudo pode ser completamente remexido e reordenado de todas as maneiras possíveis. (CALVINO, 1995, p. 138)

O quinto leitor difere do quarto quanto ao tempo onde se localiza esse livro que o compõe.

se trata de um livro situado num passado distante, que a custo emerge de minhas lembranças. É para mim uma história anterior a todas as outras, e da qual todas as histórias que leio me parecem oferecer um eco, que logo se perde. Em minhas leituras não faço nada além de buscar esse livro lido em minha infância, mas o que me recordo é demasiado pouco para encontrá-lo. (CALVINO, 2003, p. 259)

No entanto, percebemos que a diferença no tempo, o que parecia ser um pequeno elemento diferencial, é determinante. Enquanto o quarto leitor age em suas leituras formando 
um infindável e labiríntico livro, o quinto leitor percorre esse labirinto em busca de um livro evanescente, sempre a se mostrar, mas nunca a se revelar por completo.

O sexto leitor afirma que aquilo que precede a leitura do texto em si é mais importante para ele. Ele fala da "promessa de leitura" (CALVINO, 2003, p. 259), de modo que, nessa concepção, são necessários menos estímulos para que a imaginação seja movimentada. Por vezes, basta-lhe o título para provocar o desejo pelo livro que, talvez, exista apenas na imaginação fomentada por essa tal frase.

Por outro lado, ao sétimo leitor, o mais importante é o fim, "mas o final verdadeiro, o derradeiro, oculto na escuridão, o ponto de chegada ao qual o livro quer conduzi-lo" (CALVINO, 2003, p. 259). E acrescenta: “Ao ler, eu também procuro um respiradouro [...], mas, se meu olhar escava entre as palavras é para tentar discernir o que se esboça à distância, nos espaços que se estendem para além da palavra "fim"” (CALVINO, 2003, p. 259). De modo que o livro não se esgota na experiência linguística e invade a experiência vivida, viajando para além do seu encerramento físico e linguístico.

O oitavo leitor é metódico e "fiel" ao livro enquanto objeto, declarando: "o que mais gosto mesmo é de ler um livro do princípio ao fim" (CALVINO, 2003, p. 259). A ele, "agrada ler nos livros só o que está escrito e ligar os detalhes ao conjunto; considerar definitivas certas leituras; não misturar um livro com outro; separar cada um por aquilo que possui de diferente e de novo" (CALVINO, 2003, p. 259). Intertextualidade e "acabado interrompido" são estratégias narrativas que não lhe dão prazer.

Nessas representações literárias do leitor, Calvino evidencia manifestações diversas de leitores, mas o Leitor, o protagonista, evidencia uma concepção de leitor que se alinha ao defendido por Iser e Eco.

Segundo Iser, o leitor é orientado pelo não dito; as indeterminações são os elementos em ausência que possibilitam ao leitor empregar seu espírito criativo à obra na interação com ela. Esta teoria aproxima-se do desenvolvido por Umberto Eco na teoria da obra aberta.

Eco postula que "um texto é um mecanismo preguiçoso (ou econômico) que vive da valorização de sentido que o destinatário ali introduziu" (ECO, 1986, p. 37), e "à medida que passa da função didática para a estética, o texto quer deixar ao leitor a iniciativa interpretativa" (ECO, 1986, p. 37). Dessa forma, o texto mostra-se aberto para a interpretação do leitor, momento em que a obra alcança dimensão estética.

O Leitor, nessa obra de Calvino, é propriamente o elemento que constitui o texto em objeto estético, tomando-o para si e ressignificando-o. 
A figura do leitor é ressaltada e destacada na narrativa, tornando a recepção um assunto não acessório, mas essencial para a compreensão da obra e da sua criação, na medida em que o receptor é também, em contribuição, criador da obra.

Essa circunstância de imbricação, por meio da metaficção, entre criação e recepção, escrita e leitura, ou, ainda, de recepção produtiva pode ser discutida a partir da figura de Escher: Drawing hands [em português, "Mãos que se desenham"] — a mão direita desenha a mão esquerda, que, por sua vez, desenha a direita -, em que uma compõe a outra, misturando-se, nesse enigma da metaficção, em que a ficção se faz ficção na própria ficção, mas não abandona por completo a realidade. Tem-se ficção e realidade na ficção, o que é traçado (receptor-emissor) e o que traça (emissor-receptor) nesse entrelugar onde as duplicidades coexistem de modo ambivalente, ambíguo.

Figura 1 - Drawing hands (1948), de Escher

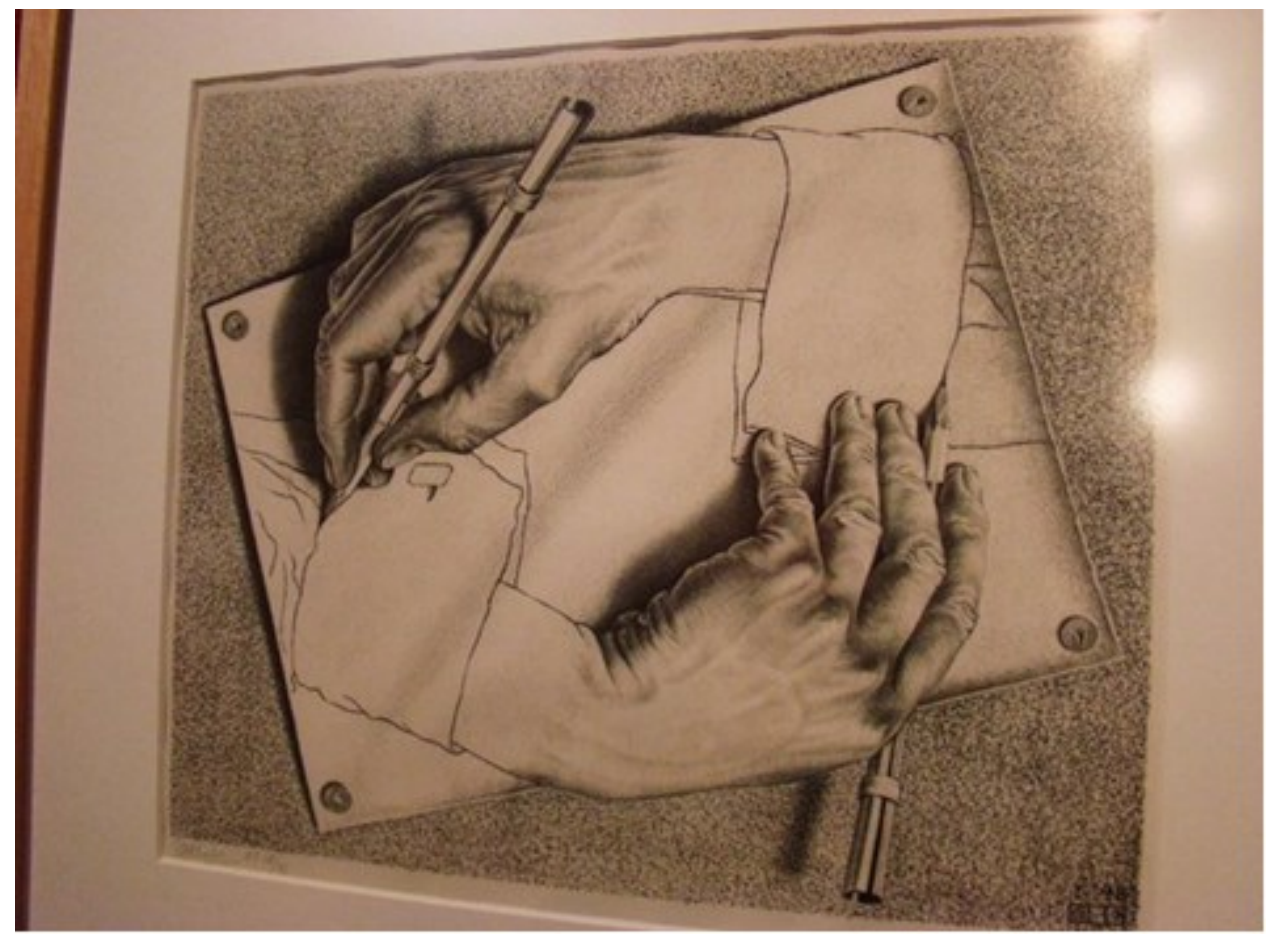

Fonte: ESCHER, Maurits. Drawing hands (1948). Disponível em: http://www.mcescher.com/gallery/mathematical/drawing-hands/. Acesso em: 01 out. 2013.

Bhabha elucida que os sujeitos interagem em um entrelugar, "trânsito em que espaço e tempo se cruzam para produzir figuras complexas de diferença e identidade, passado e presente, interior e exterior, inclusão e exclusão" (BHABHA, 1998, p. 19).

E, ao observar a figura, percebe-se que, no ambiente do metaliterário, nesse entrelugar de teoria e ficção bem como de criação e recepção, a recepção, assim como a criação, é criativa, produtiva. Não se pode falar, portanto, de um receptor passivo, mas de um 
que, ao ser formado, também forma. Essa é uma temática central de Italo Calvino em Se um viajante numa noite de inverno. Essa obra materializa a evidente inter-relação de escrita e leitura e evidencia o papel ativo que o leitor deve desempenhar na recepção literária, parecendo responder ao questionamento que o personagem Leitor faz: "E eu? Que papel devo desempenhar?" (CALVINO, 2003, p. 219).

\section{Referências}

AGUIAR, Vera de. O leitor competente à luz da teoria literária. Revista Tempo Brasileiro, Rio de Janeiro, v. 124, p. 23-34, jan./mar. 1996.

BAUDRILLARD, Jean. Simulacros e simulação. Lisboa: Relógio d’água, 1991.

BHABHA, Homi. O local da cultura. Belo Horizonte: Editora UFMG, 1998.

BORGES, Jorge Luis. Obras completas de Jorge Luis Borges. São Paulo: Globo, 1999. v. 3. . Sete noites. Tradução de João Silvério Trevisan. São Paulo: Max Limonad, 1983.

CALVINO, Italo. Se um viajante numa noite de inverno. Trad. de Nilson Moulin. São Paulo: Planeta De Agostini, 2003.

. Seis propostas para o próximo milênio: lições americanas. Trad. de Ivo Barroso. 2. ed. São Paulo: Companhia das Letras, 1995.

COMPAGNON, Antoine. O demônio da teoria: literatura e senso comum. Trad. de Cleonice Paes Barreto Mourão e Consuelo Fortes Santiago. Belo Horizonte: Ed. UFMG, 1999.

ECO, Umberto. Lector in fabula: a cooperação interpretativa nos textos narrativos. Trad. de Attilio Cancian. São Paulo: Perspectiva, 1986.

ESCHER, Maurits. Drawing hands (1948). Disponível em: http://www.mcescher.com/gallery/mathematical/drawing-hands/. Acesso em: 01 out. 2013.

GUIDIO, Milena. Reflexões sobre a posição do leitor nas teorias da recepção. Disponível em: http://www.albertolinscaldas.unir.br/posicaodoleitor.htm. Acesso em: 13 out. 2013.

ISER, Wolfgang. A interação do texto com o leitor. In: COSTA LIMA, Luiz (Org.). A literatura e o leitor: textos de estética da recepção. Seleção, coordenação e tradução de Luiz Costa Lima. Rio de Janeiro: Paz e Terra, 1979, p. 83-132.

. O ato da leitura: uma teoria do efeito estético. Trad. de Johannes Kretschmer. São Paulo: Ed. 34, 1996. v. 1.

MANGUEL, Alberto. Uma história da leitura. São Paulo: Companhia das Letras, 1997.

PENSADOR.INFO. Pensamento de Heráclito. Disponível em: http://pensador.uol.com.br/pensamento_de heraclito/. Acesso em: 13 out. 2012. 
PESSOA, Fernando. Autopsicografia. In:

Obra poética e em prosa. Introdução, organização, biobibliografia e notas de António Quadros e Dalila Pereira da Costa. Porto: Lello \& Irmão Editores, 1986. v. I: Poesia. p. 314.

The essayism present in If on a winter's night a traveler, by Italo Calvino: a theory of reading, in a metafiction novel

Abstract: This study proposes a reflection on how the thinker Italo Calvino show, in If on a winter's night a traveler (1979), a theory of reading. In this novel, while the writer narrates the attempt of the character called Reader to finish the reading of a book, he also speculates about the reader and the reading. Among the many possibilities of analysis of this work, bearing in mind its multiplicity, here is focused the exhibition, in the text itself, of the process of writing of the novel and its fictional nature. The clipping chosen has its relevance justified by the proposition of Jean Baudrillard in Simulacra and simulation (1991): the "promise" (because had not yet been revealed at the time of this publication) of the third category of simulacra, in which there is no longer the isolation of fiction and theory, and the lack of distinction between the imaginary and the real would pave the way for the presentification of the metatechnique; this category is perceived in the work studied and it is, according to Baudrillard, what can still interest us. If on a winter's night a traveler, because it is a space of metafictional articulation, is a fruitful environment for interaction between fiction and theory, and it is, therefore, even more productive to the debate on the figure and the function of the reader. It is precisely the metafictional aspect related to the reader's figure and to its activity which is tracked in this text that the writer himself called hyper-romance. For this reason, it identifies and analyzes some distinctive aspects of this work as: how to read, types of books, the art of not-read, reader and reading; and so the literary object of study is also part of the selected theoretical corpus. To the fictional and theoretical production of Italo Calvino, the theoretical constructs of Wolfgang Iser and Jorge Luis Borges are added, for the comprehension and analysis of that literary text, with the focus on the central themes developed here: reader and reading.

Keywords: Italo Calvino. Reader. Reading. Metafiction.

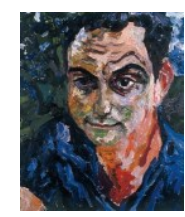

